\title{
Dependable Flow and Flood Control Performance of Logung Dam, Central Java Province, Indonesia
}

\author{
Faza Ramadhani \\ PT. Wijaya Karya (Persero) Tbk, Jakarta, INDONESIA \\ ramadhanfaza@gmail.com
}

\begin{abstract}
The change of land use in Mt. Muria area Central Java has been resulting in the significant sheet erosion of upstream watershed around Mt. Muria, followed by considerably high sedimentation on rivers downstream that lead to the reduction of cross sections of the rivers including Logung River. Such situation has been contributing the condition that downstream of Logung River is very potential to experience over flow and inundation to its surrounding area. An idea of constructing the Logung Dam was introduced in 1986 that aimed at reducing the aforementioned inundation. Besides, the development of Logung Dam was also aimed at fulfilling both irrigation and non-irrigation water demand. This paper presents the results of the analysis of the water availability and flood control performance of the Logung Dam. The dependable flow was analyzed by applying the National Rural Electric Cooperative Association (NRECA) method in order to determine the low flow characteristics, whereas the identification of the high flow characteristics was carried out by using the Synthetic Unit Hydrograph (SUH) methods, i.e., the GAMA I and Nakayasu modeling approach. At a certain reservoir characteristic and a defined geometry of spillway, several reservoir routing simulations were carried out on both dependable flows and high flows. Results of the reservoir routing showed the promising water availability of the Logung Dam to fulfill water demand for both irrigation and non-irrigation, whereas the reservoir routing could reduce the probable maximum flood from QPMF from 1,031 ms to approximately $950 \mathrm{~m}^{3} / \mathrm{s}$ or damping efficiency at $7.86 \%$. Further analysis suggests necessary operation and maintenance of Logung Dam to sustain its function and to mitigate possible problems related to reservoir sedimentation.
\end{abstract}

Keywords: Spillway routing, design flood, dependable flow

\section{INTRODUCTION}

The change of land use in Mt. Muria area has resulted in erosion at the upstream part and sedimentation on rivers in the downstream part. Study on the planning and development of Logung Dam have been carried out since 1986 and addressed at reducing flood The Logung Dam is located in the downstream part of the confluence between Logung River Gajah River Slalang Sub-village, Tanjungrejo Village, District of Jekulo, Kudus Regency. The watershed area of Logung Dam is about $43.81 \mathrm{~km}^{2}$ with the storage capacity is about 20,150,000 $\mathrm{m}^{3}$ (Ramadhani, 2017). The Logung Dam development was intended to control flood and other additional purposes such as to avail water for irrigation and non-irrigation demand. The function of the Logung Dam to control the flood as targeted to reduce the frequency some area in Kudus Regency (PT. Ika Adya Perkasa, 2014). As a flood control, the flood damping at various flood discharges should be studied and the results should indicate the promising damping efficiency. The objectives of this study are to analyze the capacity of the reservoir to control flood at several on return periods, i.e., 100 years, 1,000 years, 2,000 years, and the PMF, as well as to analyze the water availability and through flood routing of the low flow. Simulation of high flow hydrograph in this study was based on the GAMA I and Nakayasu methods, while for the case of low flow hydrograph, it applied the National Rural Electric Cooperative Association (NRECA) method. Development of reservoir routing program to analyze both the high flow and low flow as performed at certain reservoir characteristics and spillway geometry.

\section{PREVIOUS STUDIES}

\subsection{Probable Maximum Precipitation}

The Probable Maximum Precipitation (PMP) is usually defined as maximum precipitation depth during a given period that is physically possible over a particular drainage area. In general, this PMP ranges from 2 up to 6 times of rainfall return period of 100 years according to RSNI T-02-2004 (Badan Standardisasi Nasional, 2014).

\subsection{Design Flood Discharge}

Design flood discharge is the flood discharge that may be used to design the hydraulic structures including dams. After all, factors are considered to contribute rainfall, the considerably greatest runoff can be obtained according to SNI 03-3432-1994 (Badan Standardisasi Nasional, 1994). Design flood discharge 
can be calculated with several methods, among others are the rational method, Weduwen method, Melchior method, and synthetic unit hydrograph method. The synthetic unit hydrograph calculation is based on the watershed characteristic. The synthetic unit hydrograph could be calculated with various methods, such as the GAMA I Synthetic Unit Hydrograph and Nakayasu Synthetic Unit Hydrograph.

\subsection{Evapotranspiration}

Evapotranspiration is one of process link in the hydrological cycle. Evaporation occurs on all surfaces that contain water (moisture), such as the water surface, land surface, plant surface, or the vegetated surface; although it has been well known that sea water evaporation is the largest evaporation (Allen, et al., 1998; Doorenbos \& Puitt, 1977). The number value of evaporation can be calculated with theoretical approaches. Some of the theoretical approaches that can be used are empirical equations, water balance, aerodynamic method, energy balanced method, combination method and Priestly-Taylor method (Sri Harto, 2009).

\subsection{Transformation of Rainfall to Runoff}

According to Griffiths (2014), there are various models on rainfall-runoff transformation, such as the Water Balance Models (Thornhwaite \& Mather, 1955), Reservoir Models (Horton, 1938), Tank Models (Sugawara, 1995), and Land-Cover and Soil Properties. Transformation models that are commonly used for Indonesian area are the Mock model, NRECA model, and Tank Model. The Mock model and NRECA model concepts generally use the water balance principle, which is similar to the theory of Water Balance Models (Nanti, 2007).

\subsection{Reservoir Definition and Function}

A reservoir is a water storage constructed by the concept of storing water at high discharge event or during rainy seasons and releasing it at low discharge event or during dry seasons (Sudjarwadi, 2008). Reservoirs have several functions, regarding the utilization, reservoirs are categorized into two types, namely single purpose reservoirs and multipurpose reservoirs. The single purpose reservoir has a distinctive function, only devoted to single utilization, such as irrigation reservoir, hydropower reservoir, flood control reservoir, and others. While the multipurpose reservoir has more than a single utilization, for example, a combination of irrigation, hydropower, and water supply (Hardianto, 2015).

\subsection{Spillway Routing}

According to Kodoatie and Sjarief (2006), flood routing in a reservoir is intended to examine the characteristic of outflow hydrograph. The outflow is a function several factors such as inflow hydrograph, reservoir characteristics, and spillway geometry. Under any condition of the aforesaid factors, water surface elevation in the reservoir may not exceed the dam crest elevation.

\subsection{Intake Structure (Tunnel) Routing}

Tunnel routing in the reservoir is conducted to analyze the water elevation of the reservoir by using dependable discharge on certain probability. If the water elevation is higher than the gate of intake channel, water can be released, and thus water supply for irrigation or non-irrigation use can be provided. In contrary, if the water elevation is lower than intake gate, then water release is not available, and water demand cannot be fulfilled.

\section{THEORETICAL APPROACH}

\subsection{Rainfall Analysis}

\subsubsection{Probable Maximum Precipitation (PMP)}

Probable Maximum Precipitation used in this research was statistical approach which used Hershfield method (Badan Standardisasi Nasional, 2014) as shown in Equation 1.

$$
X_{m}=\bar{X}_{P}+K_{m} S_{P}
$$

where $X_{m}$ represents probable maximum precipitation and $\bar{X}_{p}$ is mean of annual daily maximum rainfall data series of $\mathrm{n}$ corrected with adjustment factor, $K_{m}$ is function value of rainfall duration and mean of annual daily maximum rainfall, $S_{p}$ is standard deviation of annual daily maximum rainfall data series of $n$ corrected with adjustment factor

\subsubsection{Rainfall Concentration Time}

Rainfall concentration time is derived from the automatically recorded rainfall data so that the typical pattern of rainfall distribution could be determined. One of the methods that could be used to estimate the time of concentration is the Bransby-Williams equation,

$t_{c}=0.243 L A^{0.1} S^{0.2}$

where $t_{c}$ is time of concentration (hours), $A$ is watershed area $\left(\mathrm{km}^{2}\right), L$ is length of main river $(\mathrm{km})$, and $S$ is slope of main river. 


\subsection{Hydrology Data Frequency Analysis}

Frequency analysis uses a lot of annotations or statistical theories that processed based on the data to be used. Data used in the frequency analysis was maximum annual rainfall data, which is the largest data that occurs in a year.

\subsection{Synthetic Unit Hydrograph}

\subsubsection{GAMA I Synthetic Unit Hydrograph (SUH)}

GAMA I Synthetic Unit Hydrograph consists of three main parts, which are the rising limb, peak (crest), the recession limb (Sri Harto, 2009). It also consists of four main variables, which are the time of rising $\left(T_{R}\right)$, the peak discharge $\left(Q_{p}\right)$, base time $\left(T_{B}\right)$, and recession side that determined with storage coefficient value $(K)$; more details are shown in Figure 1.

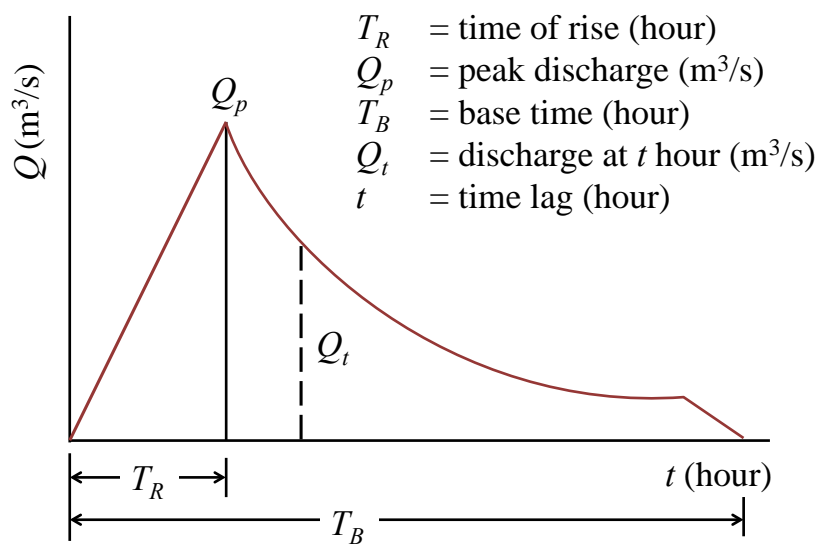

Figure 1. GAMA I Synthetic Unit Hydrograph

$$
Q_{t}=Q_{p} e^{-t / K}
$$

Other than the above equation, there is also an additional equation to the infiltration effect, which is the infiltration index or $\Phi_{\text {index }}$.

$$
\Phi_{\text {index }}=10.4903-3.859 \cdot 10^{-6} A^{2}+1.6985 \cdot 10^{-13}\left(\frac{A}{S N}\right)^{4}
$$

which $\Phi_{\text {index }}$ is infiltration index ( $\mathrm{mm} /$ hour), and $S N$ is frequency source.

\subsubsection{Nakayasu Synthetic Unit Hydrograph (SUH)}

Nakayasu Synthetic Unit Hydrograph came from Japan, where the unit hydrograph has been researched on some of the rivers. This Synthetic Unit Hydrograph is widely used in reservoir construction and several rivers in various locations, such as in the Brantas River (East Java) project. More details on Nakayasu Synthetic Unit Hydrograph are shown in Figure 2 (Chow, et al., 1988).
$Q_{P}=\frac{1}{3.6}\left(\frac{A R_{e}}{0.3 T_{p}+T_{0.3}}\right)$

$T_{P}=T_{g}+0.8 T_{r}$

$T_{g}=0.4+0.058 L$

$T_{g}=0.21 L^{0.7}$

$T_{0.3}=\alpha T_{g}$

$T_{r}=0.5 T_{g}-T_{g}$

which $R_{e}$ is effective unit rain $(1 \mathrm{~mm}), T_{p}$ is time interval from the beginning of flood to peak hydrograph (hour), $T_{0.3}$ is time interval from the beginning of peak flood to 0.3 times peak discharge (hour), $T_{g}$ is time of concentration (hour), $T_{r}$ is time unit of rainfall (hour), $\alpha$ is watershed characteristic coefficient, commonly used 2 .

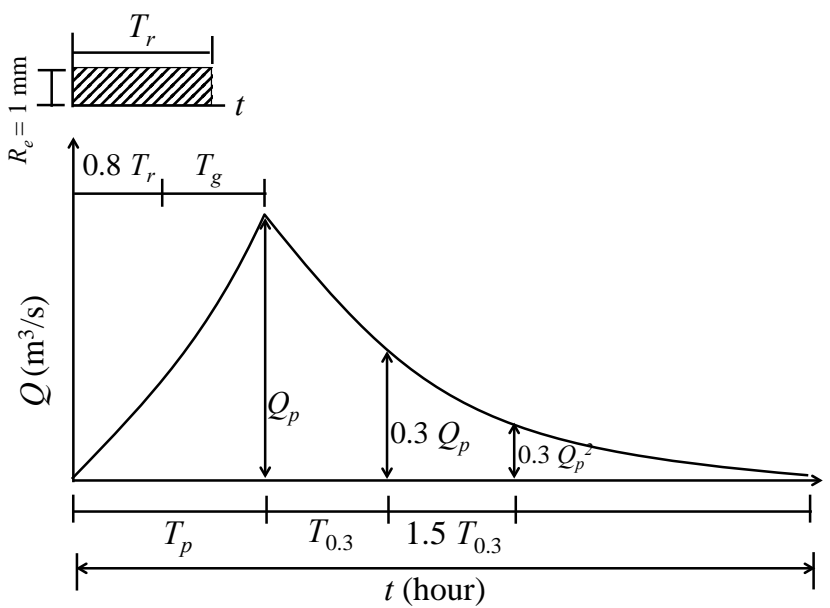

Figure 2. Synthetic Unit Hydrograph Nakayasu

The shape of unit hydrograph given by the following equation:

Curved up $\left(0<\mathrm{t}<T_{p}\right)$

$Q_{t}=Q_{p}\left(\frac{t}{T_{p}}\right)^{2.4}$

Curved down $\left(T_{p}<t<T_{p}+T_{0.3}\right)$

$Q_{t}=Q_{P} \cdot 0.3^{\left(t-T_{p}\right)} / T_{0.3}$

Curved down $\left(T_{p}+T_{0.3}<t<T_{p}+T_{0.3}+1.5 T_{0.3}\right)$

$\left.Q_{t}=Q_{p} \cdot 0.3^{\left[\left(t-T_{p}\right)+\left(0.5 T_{0.3}\right) /\left(1.5 T_{0.3}\right)\right.}\right]$ 
Curved down $\left(t>T_{p}+T_{0.3}+1.5 T_{0.3}\right)$

$\left.Q_{t}=Q_{p} \times 0.3^{\left(t-T_{p}\right)+\left(1.5 T_{0.3}\right) /\left(2 T_{0.3}\right)}\right)$

\subsection{Evapotranspiration}

In this research, the used method was an empirical equation, Thornthwaite method (Thornhwaite \& Mather, 1955) which can be seen in Equation 15 and Equation 16.

$$
E T_{\text {month }}=1.62\left(\frac{10 T_{m}}{I}\right)^{a}
$$

with:

$$
I={ }_{m=1}^{12} \frac{T_{m}}{5} \div
$$

which $E T_{\text {month }}$ denotes monthly potential evapotranspiration $(\mathrm{cm}), T_{m}$ is average monthly temperature $\left({ }^{\circ} \mathrm{C}\right)$, and $I$ is annual heat index.

\subsection{NRECA Rainfall-Runoff Transformation Model}

The principle of NRECA model is to estimate the amount of river flow discharge due to the rain occurred in the watershed area, by taking into account the soil condition and topography. According to Griffiths (2014), there are various models on rainfall-runoff transformation, such as the Water Balance Models (Thornhwaite \& Mather, 1955), Reservoir Models (Horton, 1938), Tank Models (Sugawara, 1995), and Land-Cover and Soil Properties. Transformation models that are commonly used for Indonesian area are the Mock model, NRECA model, and Tank Model. The Mock model and NRECA model concepts generally use the water balance principle, which is similar to the theory of Water Balance Models.

\subsection{Governing Equations of Reservoir Routing}

Routing is a procedure to determine the time-discharge relationship of the flow (flow hydrograph) at a downstream point based on the observed hydrograph at the upstream side. If the flow is a flood, the procedure then would be known as flood routing. Flood routing is widely used in flood control studies, in which the analysis can be conducted alongside a river or on a reservoir. The reservoir routing is expressed in continuity equation as follows:

$$
I-O=\frac{d S}{d t}
$$

where $I$ is inflow to river segment $\left(\mathrm{m}^{3} / \mathrm{s}\right), O$ is outflow from river segment $\left(\mathrm{m}^{3} / \mathrm{s}\right), d S$ is a change of storage in river segment $\left(\mathrm{m}^{3}\right), d t$ is routing time interval (second, hour, or day).

\subsubsection{Routing through Spillway}

The flow through the spillway $\left(O_{s}\right)$ depends on the width of the spillway $(B)$, height of the overflow $(H)$, and the discharge coefficient $\left(C_{d}\right)$ as given by Equation 18.

$O_{s}=C_{d} B H^{3 / 2}$

\subsubsection{Routing through Intake Structure (Tunnel)}

The general formula for calculating the outflow through the intake structure (tunnel) depends on the cross section area of the tunnel $(A)$, and the flow velocity in the tunnel (v), as shown in Equation 19.

$$
O=A \cdot V
$$

\section{ANALYSIS, RESULTS, AND DISCUSSIONS}

\subsection{General}

As it is mentioned in the previous section, the functional design of the Logung Dam is addressed at two different targets. The first targets are to fulfill the irrigation and non-irrigation water demand, and the second target is to reduce flood discharge (especially in the wet season). The inflow hydrograph under two different conditions, i.e. the dependable flow (low flow) and the flood flow (high flow) condition, should be initially determined. In order to determine this two inflow hydrographs, the followings data were used:

a) Rainfall data

b) Monthly rainfall data

c) Climatology data

d) Watershed parameter data

e) Reservoir technical data

The analysis of the design flood discharge requires the design rainfall duration of the design of the maximum daily rainfall. As for the dependable discharge was obtained from the calculation of monthly rainfall data, which in this research was analyzed by using the NRECA model.

\subsection{Design Rainfall Duration}

The equation used in calculation of the time of concentration was the Bransby-Williams equation.

a) Watershed area $(A): 43.81 \mathrm{~km}^{2}$

b) Main river length $(L): 20.125 \mathrm{~km}$

c) Main river slope $(S): 0.06$ 
$t_{c}=0.243 \cdot L \cdot A^{0.1} \cdot S^{-0.2}=5.882$ hours $\sim 6$ hours

In this research, the hourly distribution of the rainfall was derived by Alternating Block Method (ABM). A value of rainfall in a daily basis and the value of $\Phi_{\text {index }}$ is necessary for the input of ABM method. The $\Phi_{\text {index }}$ value was determined by Equation 4. For instance, the design rainfall distribution for 100 years returns period is shown below.

\section{$P_{100}: 261.187 \mathrm{~mm}$ \\ $\Phi_{\text {index }} \quad: 10.483 \mathrm{~mm}$}

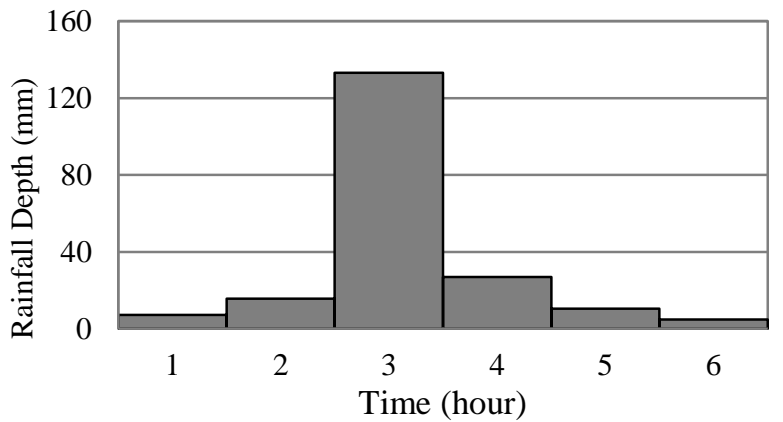

Figure 3. Rainfall distribution with ABM Method (100 years)

\subsection{GAMA I Synthetic Unit Hydrograph}

Table 1 shows the parameters of Logung Watershed used for deriving GAMA I Synthetic Unit Hydrograph.

Table 1. Logung watershed parameter for deriving GAMA I Synthetic Unit Hydrograph

\begin{tabular}{llll}
\hline Watershed parameter & Symbol & Value & Unit \\
\hline Watershed area & $A$ & 43.81 & $\mathrm{~km}^{2}$ \\
Main river length & $L$ & 20.13 & $\mathrm{~km}$ \\
Level 1 river length & $L 1$ & 40.88 & $\mathrm{~km}$ \\
All level river length & $L N$ & 98.63 & $\mathrm{~km}$ \\
Level 1 river segment & $A$ & 5.03 & \\
All level river segment & $B$ & 15.09 & \\
River encounter & $J N$ & 36.00 & \\
Watershed width on 0.25 & $W_{L}$ & 4.95 & $\mathrm{~km}$ \\
river length & & & \\
Watershed width on 0.75 & $W_{U}$ & 3.00 & $\mathrm{~km}$ \\
river length & & & \\
Watershed area on & $A U$ & 17.40 & $\mathrm{~km}$ \\
upstream & & 0.06 & \\
River slope & $S$ & 0.41 & \\
Source factor & $S F$ & 0.52 & \\
Source frequency & $S N$ & 0.61 & \\
Width factor & $W F$ & & \\
Watershed relative area & $R U A$ & 0.40 & \\
size on upstream & & & \\
Symmetry factor & $S I M$ & 0.24 & \\
River encounter number & $J N$ & 37.00 & \\
Drainage density & $D$ & 2.25 & $\mathrm{~km} / \mathrm{km}^{2}$ \\
\hline
\end{tabular}

The watershed parameters on Table 1 then were processed to obtain the main parameters of GAMA I Synthetic Unit Hydrograph as shown in Table 2. These parameters are graphed and the shape of the hydrograph is presented in Figure 4.

Table 2. GAMA I Synthetic Unit Hydrograph Main Parameter

\begin{tabular}{lll}
\hline Parameter & Value & Unit \\
\hline$T_{R}$ & 1.58 & hour \\
& 2.00 & hour \\
$Q_{P}$ & 3.04 & $\mathrm{~m}^{3} / \mathrm{s}$ \\
$T_{B}$ & 19.55 & hour \\
$K$ & 4.51 & \\
$Q_{B}(\mathrm{BF})$ & 11.67 & $\mathrm{~m}^{3} / \mathrm{s}$ \\
$\Phi_{\text {index }}$ & 10.483 & $\mathrm{~mm} /$ hour \\
\hline
\end{tabular}

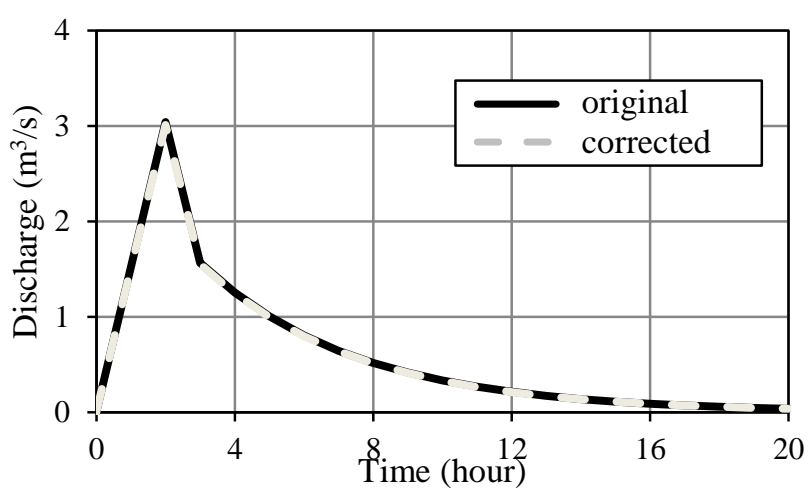

Figure 4. GAMA I Synthetic Unit Hydrograph original and corrected

\subsubsection{Nakayasu Synthetic Unit Hydrograph}

Similar to the GAMA I Synthetic Unit Hydrograph, several parameters of the watershed is necessary for calculating the Nakayasu Synthetic Unit Hydrograph equations. Table 3 gives the input and output of Nakayasu Synthetic Unit Hydrograph calculation.

Table 3. Nakayasu Synthetic Unit Hydrograph Calculation Input and Output

\begin{tabular}{llll}
\hline Parameter & Symbol & Value & Unit \\
\hline Input & & & \\
Watershed area & $A$ & 43.81 & $\mathrm{~km}^{2}$ \\
Main river length & $L$ & 20.13 & $\mathrm{~km}$ \\
Unit rain & $R_{o}$ & 1 & $\mathrm{~mm}$ \\
Watershed & $\alpha$ & 2 & \\
characteristic & & & \\
coefficient & & & \\
Output & & & \\
Time of concentration & $T_{g}$ & 1.57 & hour \\
(Time Lag) & $T_{r}$ & 1.18 & hour \\
& $T_{0.3}$ & 3.13 & hour \\
Peak time & $T_{p}$ & 2.51 & hour \\
& & 3 & hour \\
Peak discharge & $Q_{p}$ & 3.02 & m $3 / \mathrm{s}$ \\
\hline
\end{tabular}


The main parameters of Nakayasu Synthetic Unit Hydrograph given in Table 3 are then plotted on the graph as shown in Figure 5.

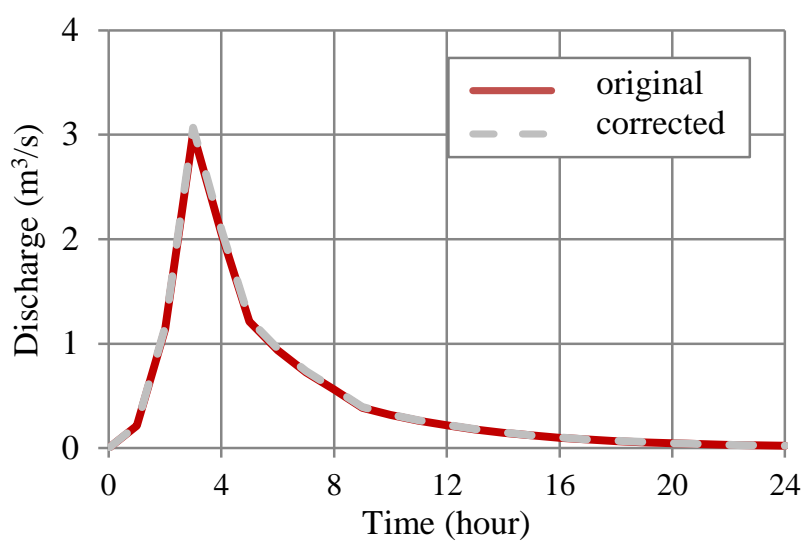

Figure 5. Nakayasu Synthetic Unit Hydrograph original and corrected

\subsection{Flood Hydrographs}

\subsubsection{GAMA I Flood Hydrograph}

Flood discharge hydrographs were derived from the GAMA I Synthetic Unit Hydrograph (SUH). Flood hydrographs for various return period $(2,5,10,100$, 500, 1000, 2000 years and PMF) are derived (Figure $6)$. Rainfall duration was assumed 6 hours.

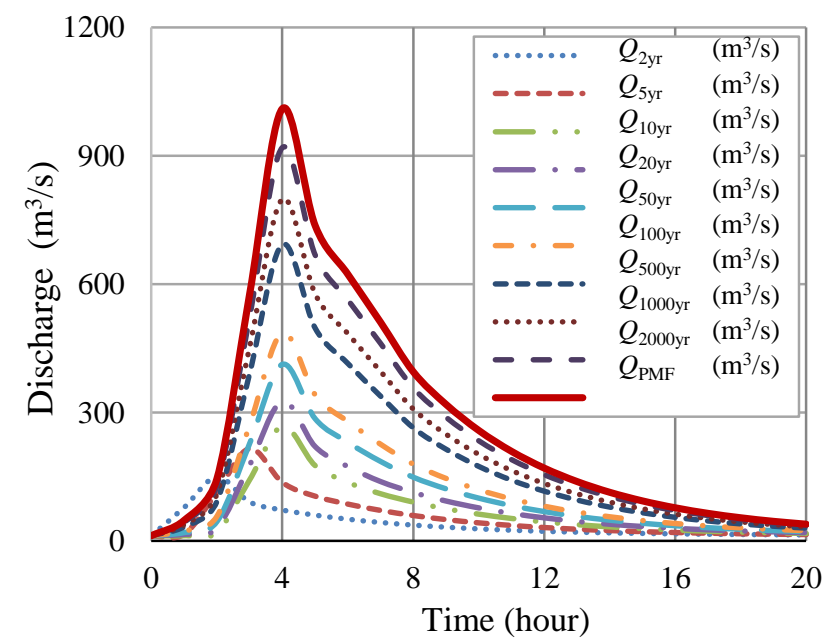

Figure 6. Flood Hydrograph calculated using GAMA I Synthetic Unit Hydrograph

\subsubsection{Nakayasu Flood Hydrograph}

The flood discharge hydrographs were also calculated with Nakayasu Synthetic Unit Hydrograph and an assumption that rainfall was distributed in 6 hours duration. Figure 7 depicts flood hydrographs for 2, 5, 10, 100, 500, 1000, 2000-years return period and PMF.

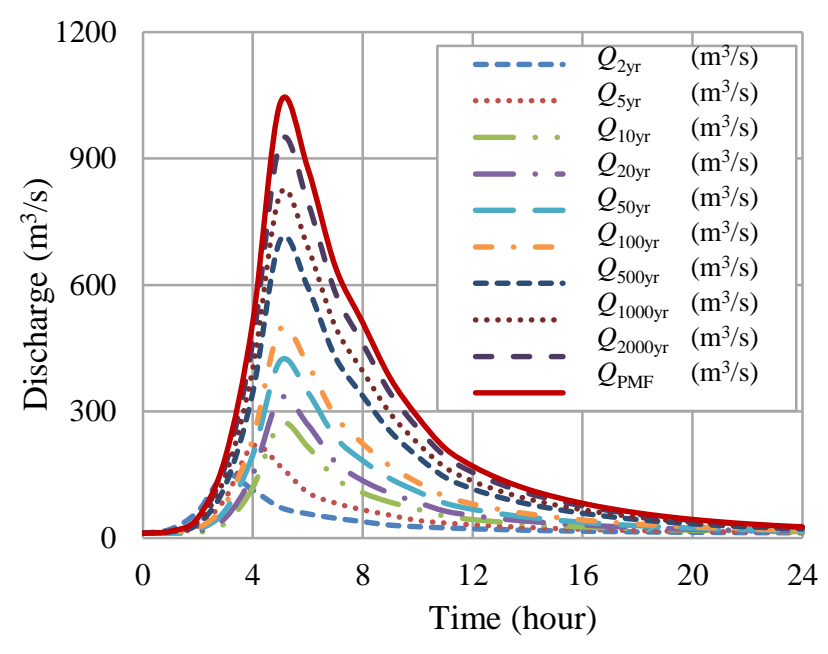

Figure 7. Flood Hydrographs calculated with Nakayasu Synthetic Unit Hydrograph

\subsection{Dependable Discharge NRECA}

In the dependable discharge analysis (low flow), the amount of discharge was calculated with the NRECA simulation model. The method of NRECA model has been explained in Section 3. Data processing with NRECA model needs several parameters, i.e. the maximum rainfall (1970-2009) reduction number, sub surface percentage, ground water flow, and monthly potential evaporation value. The results of $80 \%, 90 \%$ and $100 \%$ dependable discharge calculation were presented in Figure 8.

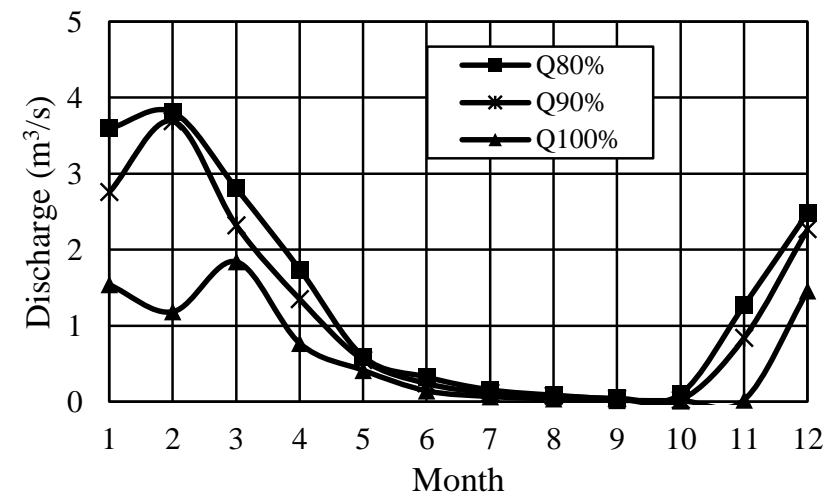

Figure 8. Dependable Discharge of $80 \%, 90 \%, 100 \%$

\subsection{Reservoir Routing}

\subsubsection{High Flow Routing}

The technical data of Logung Dam spillway are listed below:
a) Type: Side Spillway with Ogee without gate
b) Peak elevation: $+88.50 \mathrm{~m}$
c) Width: $50 \mathrm{~m}$ 
Equation 20 to Equation 26 are water balance formula for reservoir routing. The change of storage in a reservoir $(\Delta S)$ at a time period $(\Delta t)$ depends on inflows $(I)$ and outflows $(O)$.

$$
\bar{I} \Delta t-\bar{O} \Delta t=\Delta S
$$

where:

$$
\begin{gathered}
\bar{I}=\frac{I_{1}+I_{2}}{2} \\
\bar{O}=\frac{O_{1}+O_{2}}{2} \\
S=S_{2} \quad S_{1}
\end{gathered}
$$

if the value of $I, O$, and $\Delta S$ were substituted, then:

$\frac{I_{1}+I_{2}}{2} \Delta t-\frac{O_{1}+O_{2}}{2} \Delta t=S_{2}-S_{1}$

By entering the value $\Delta t=1$ hour $=3600 \mathrm{~s}$, it resulted to:

$$
\frac{I_{1}+I_{2}}{2} \div 3,600 \quad \frac{O_{1}+O_{2}}{2} \div 3,600=S_{2} \quad S_{1}
$$

$$
1,800\left(I_{1}+I_{2}\right) \quad 1,800 O_{1}+S_{1} \quad 1,800 O_{2} \quad S_{2}=0
$$

The outflow and storage of the reservoir are the functions of the height of overflow (Equation 27 to Equation 30).

$$
\begin{aligned}
& O_{1}=C_{d} B H^{3 / 2}=2.156 \quad 50 \quad h_{1}^{3 / 2}=107.8 h_{1}^{3 / 2} \\
& O_{2}=C_{d} B H^{3 / 2}=2.156 \quad 50 \quad h_{2}^{3 / 2}=107.8 h_{2}^{3 / 2} \\
& S_{1}=V_{1}=1.2584\left(h_{1}+88.5\right)^{2.4908} \\
& S_{2}=V_{2}=1.2584\left(h_{2}+88.5\right)^{2.4908}
\end{aligned}
$$

The initial water level above the overflow, $h_{1}$, was a known variable. Therefore, the above equation is the equation with one unknown variable $h_{2}$ (water level above the overflow at the end of $\Delta t$ period). Substitution of Equation 27 - Equation 30 to Equation 26 resulted in the following equation

$$
\begin{aligned}
f\left(h_{2}\right)= & \left(I_{1}+I_{2}\right) \quad 107.8 h_{1}^{3 / 2}+0.00035\left(h_{1}+88.5\right)^{2.4908} \\
& 107.8 h_{2}^{3 / 2}+0.00035\left(h_{1}+88.5\right)^{2.4908} \\
f\left(h_{2}\right)= & 161.7 h_{2}^{3 / 2} \quad 0.00087\left(515+h_{2}\right)^{1.4908}
\end{aligned}
$$

Calculation solution, with formulation as follows,

$$
h_{2}^{n+1}=h_{2}^{n} \quad \frac{f\left(h_{2}^{n}\right)}{f^{\prime}\left(h_{2}^{n}\right)}
$$

Calculation of the flood routing through the spillway was performed using Equation 31 for 100, 1000, 2000years return period floods and Probable Maximum Flood (PMF). Figure 9 shows the inflow and outflow hydrographs through the spillway for various designed return periods.

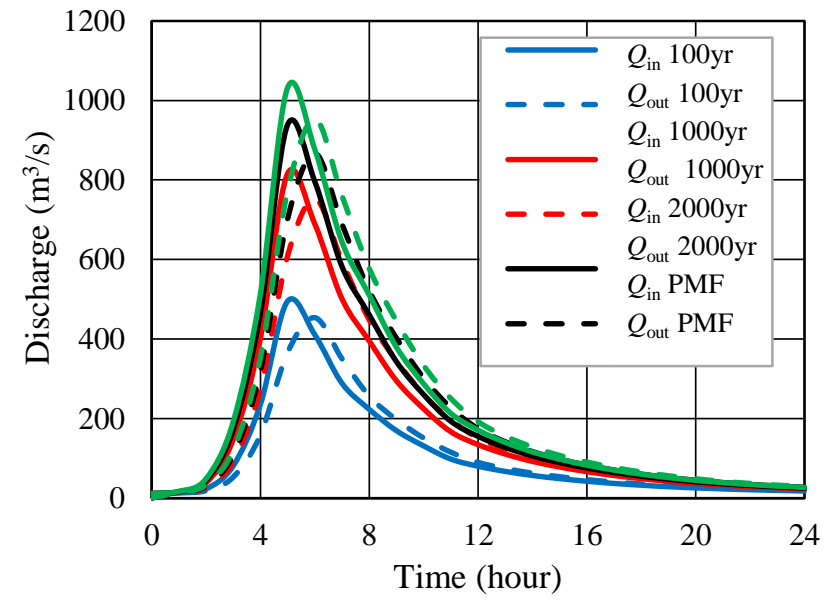

Figure 9. Inflow and outflow hydrographs

It was seen from Figure 9 that the peak discharge of QPMF inflow hydrograph and its corresponding outflow hydrograph were $1,031 \mathrm{~m}^{3} / \mathrm{s}$ and $950 \mathrm{~m}^{3} / \mathrm{s}$ respectively. It means that the flood damping efficiency is only $7.86 \%$, which is considered very low. The results of the routing also showed that under the above condition, and considering the free board requirement, the water level did not exceed the dam crest elevation. This situation indicates that the geometry of the dam and the spillway are hydraulically saved from the overtopping.

\subsubsection{Low Flow Routing}

The reservoir routing of the low flow was carried out by taking into account the intake geometry and the design of the flow to fulfill the irrigation water demand. The characteristics of the flow through the intake structure is as follows;

a) Initial water level: $+74 \mathrm{~m}$

b) Channel shape: pipe with diameter $1.2 \mathrm{~m}$ 
c) Design raw water discharge: $0.2 \mathrm{~m}^{3} / \mathrm{s}$

d) Design irrigation discharge: $2.5 \mathrm{~m}^{3} / \mathrm{s}$

e) Closure gate: $+44.55 \mathrm{~m}$

The reservoir routing through the intake channel (tunnel) was conducting with raw water and irrigation utilization which used the low flow of $80 \%$ dependable discharge. The following is the figure obtained from reservoir routing of the low flow.

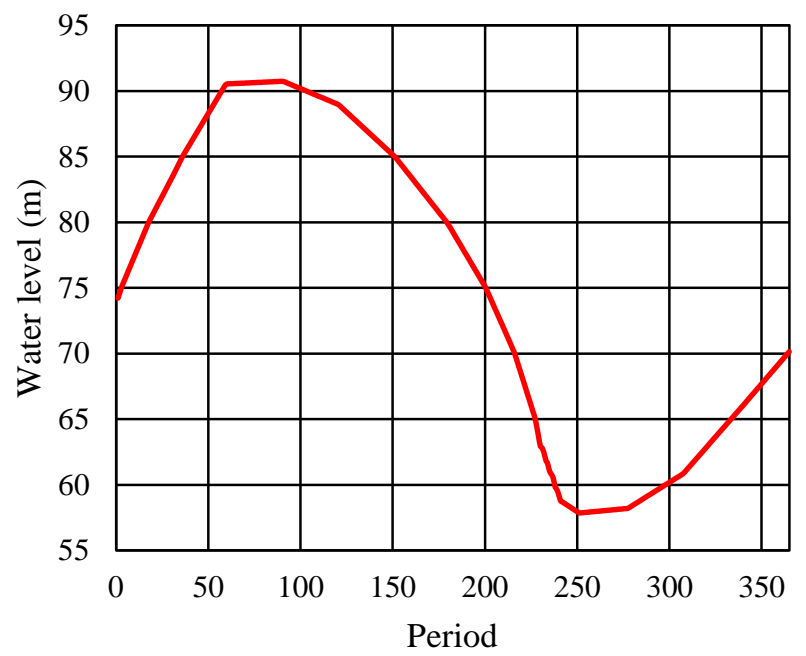

Figure 10. Water level derived from reservoir routing.

It could be seen from Figure 10 that in order to fulfill the irrigation water demand, the water level has changed. The inflow hydrograph being used in the routing was the $80 \%$ dependable flow. The result of the routing showed that water level rose significantly and hence the reservoir may store considerably large of water. The water stored in the reservoir could be used as the water supply for the irrigation and raw water to the community at the time of dry season. The result of the routing also showed that the lowest water level was $+57.85 \mathrm{~m}$ considered still exceeded the closure gate of the reservoir, so the water could enter the channel and channel the irrigation water and reservoir water.

\section{CONCLUSIONS}

The conclusions of this research are as follows:

a) From the comparison result of flood hydrograph calculation with Gama-I and Nakayasu, the method chosen was the Nakayasu, for it has higher discharge value compared to the GAMA I method.

b) The magnitude of flood discharge with return period of 100 years, 1,000 years, 2,000 years, and the Probable Maximum Flood (PMF) obtained from the Nakayasu Method are $\mathrm{Q}_{100}=495.45 \mathrm{~m}^{3} / \mathrm{s}$, $\mathrm{Q}_{1000}=815.79 \mathrm{~m}^{3} / \mathrm{s}, \mathrm{Q}_{2000}=938.36 \mathrm{~m}^{3} / \mathrm{s}, \mathrm{Q}_{\mathrm{PMF}}=$ $1031.23 \mathrm{~m}^{3} / \mathrm{s}$. c) The result of flood hydrograph (high flow) routing through spillway showed that the damping efficiency at Probable Maximum Flood condition was $7.86 \%$. Even this is considered small, however, the flood reduction at downstream Logung River remains to contribute beneficially. Whereas the result of dependable flow (low flow) routing showed that the $80 \%$ dependable flow remains sufficient to fulfill irrigation water demand.

\section{REFERENCES}

Allen, R., Pereira, L. \& Raes, D. S., 1998. Guidelines for Computing Crop Water Requirement: Crop Evapotranspiration. Rome: FAO.

Badan Standardisasi Nasional, 1994. SNI 03-34321994 Tata Cara Penetapan Banjir Desain dan Kapasitas Pelimpah untuk Bendungan [Guideline for Estimating Flood Design and Capacity of Dam Spillway]. Badan Standardisasi Nasional.

Badan Standardisasi Nasional, 2014. RSNI T-02-2004 Tata Cara Penghitungan Hujan Maksimum Boleh Jadi dengan Metode Hersfield [Guideline on Estimating Probability Maximum Rainfall based on Herfield Method]. Badan Standardisasi Nasional.

Chow, v. T., Maidment, D. \& Mays, L., 1988. Applied Hydrology. New York: Mc. Graw-Hill Book Company.

Doorenbos, J. \& Puitt, W. O., 1977. Guidelines for Predicting Crop Water Requitment: Crop Water Requirements. Rome: FAO.

Griffiths, J., 2014. Handbook of Engineering Hydrology. New York: CRC Press.

Hardianto, Y., 2015. Cengklik Reservoir Performance and Its Role for Drought Mitigation. Journal of Civil Engineering Forum, 3(1), pp. 69-76.

Horton, R. E., 1938. The Interpretation and Application of Runoff Plot Experiments. pp. 340-349.

Kodoatie, R. J. \& Sjarief, R., 2006. Pengelolaan Bencana Terpadu [Integrated Disaster Management]. Jakarta: Yayasan Watampone.

Nanti, W., 2007. Analisis Ketersediaan Air Menggunakan Neraca Air Model RAINRUN dan NRECA [Analysis of Water Availability using Water Balance Model RAINRUN and NRECA]. Yogyakarta: Department of Civil and Environmental Engineering, Universitas Gadjah Mada.

PT. Ika Adya Perkasa, 2014. Laporan Analisa Hidrologi Sertifikasi Desain Bendungan Logung di 
Kabupaten Kudus [Analysis of Hydrology for Certification Design of Logung Dam, Kudus Regency]. PT. Ika Adya Perkasa.

Ramadhani, F., 2017. Analisis Penelusuran Aliran Waduk Logung Kabupaten Kudus Provinsi Jawa Tengah [Analysis of Reservoir Routing at Logung Dam, Kudus Regency, Central Java Province], Yogyakarta: Undergraduate Thesis. Faculty of Engineering, Universitas Gadjah Mada.

Sri Harto, B., 2009. Hidrologi: Teori, Masalah dan Penyelesaian [Hydrology: Theory, Problems, and Solving]. Yogyakarta: Nafiri.
Sudjarwadi, 2008. Pengembangan Sumber Daya Air [Development of Water Resources]. Yogyakarta: Biro Penerbit Teknik Sipil UGM.

Sugawara, M., 1995. Tank Model. In: Computer Models of Watershed Hydrology. Boulder: Water Resources Publication, pp. 165-214.

Thornhwaite, C. \& Mather, J., 1955. Water Balance. Publication in Climatology, 8(1), p. 104. 
[this page intentionally left blank] 